i

: Widya Akuntansi dan Keuangan

: Universitas Hindu Indonesia

Edisi Agustus 2020

\title{
ANALISIS COMMON SIZE DAN RASIO KEUANGAN PERUSAHAAN SEKTOR INDUSTRI BARANG KONSUMSI DI BEI
}

\author{
Trisa Inna Fitriyani ${ }^{1}$ \\ Zulkarnain Zulkarnain ${ }^{2}$ \\ 1,2 Program Studi Akuntansi, Institut Manajemen Wiyata Indonesia \\ Email Korespondensi: zulkarnain@imwi.ac.id
}

\begin{abstract}
This analysis is carried out aiming to see the performance of the consumer goods industry/ CGI sector listed on the Indonesia Stock Exchange (IDX) using common size analysis and financial ratio analysis. The research method used in this research is descriptive research method. The data used is secondary data, in the form of CGI sector financial statements for the period 2017-2018, which are published on the IDX website. The data used is the financial statements of 53 companies. The source of the theory is obtained through library research and similar research obtained from research journals. Financial ratio analysis used is the current ratio, quick ratio, debt to assets, debt to equity, total asset turnover, fixed asset ratio, gross profit margin, return on assets, and return on equity. The analysis shows an increase and a decrease, and a stable number for the results.
\end{abstract}

Keywords: Common Size Analysis; Financial Ratio Analysis; Consumer Goods Industry.

\section{PENDAHULUAN}

Setiap perusahaan memiliki kewajiban untuk menerbitkan laporan keuangan. Melalui laporan keuangan dapat diketahui perkembangan dan kemajuan perusahaan. Laporan keuangan dapat menjadi alat untuk mengkomunikasikan aktivitas perusahaan atau data keuangan lainnya kepada pihak-pihak atau user yang berkepentingan (Munawir, 2014). Dengan laporan keuangan dapat diketahui kondisi keuangan perusahaan, yang dapat dilihat dari laporan posisi keuangan (neraca), laporan laba rugi, laporan perubahaan ekuitas dan laporan arus kas.

Selanjutnya untuk mendapatkan penafsiran data yang berdayaguna dilakukan analisis laporan keuangan. Hasil dari analisis laporan keuangan akan menunjukkan kinerja perusahaan dalam periode tertentu dan dapat dijadikan dasar pengambilan keputusan untuk periode masa datang. Kinerja perusahaan yang baik akan membantu pihak manajemen dalam mencapai tujuan perusahaan (Gumanti, 2011). Analisis laporan keuangan yang popular salah satunya adalah analisis rasio keuangan. 


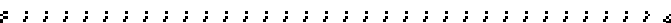

: Widya Akuntansi dan Keuangan

: Universitas Hindu Indonesia

Edisi Agustus 2020

Analisis rasio keuangan memiliki tujuan untuk mengetahui karakteristik keuangan perusahaan seperti tingkat kelancaran dalam memenuhi kewajiban (utang) jangka pendek (rasio likuiditas), kemampuan dalam memenuhi kewajiban (utang) jangka panjang (rasio solvabilitas), tingkat keuntungan (rasio profitabilitas) dan tingkat efisiensi dan efektivitas perusahaan (rasio aktivitas) (Fahmi, 2015).

Laporan keuangan selain digunakan oleh pihak internal perusahaan, pihak eksternal juga ikut serta menggunakan informasi yang ada dalam laporan keuangan. Sebagai penanam modal, investor mengharapkan perusahaan menunjukkan kinerja perusahaan yang baik, dari segi memperoleh laba ataupun efektifitas pengelolaan manajemen perusahaan.

Sebagai sumber penyedia laporan keuangan perusahaan yang listing go public di Indonesia, BEI (Bursa Efek Indonesia) menggolongkan perusahaan-perusahaan berdasarkan sektor atau jenis industrinya. Terdapat sembilan sektor industri di BEI, salah satunya adalah sektor industri barang konsumsi (Consumer Goods Industry/CGI). Perusahaan yang bergerak pada bidang pengolahan yang merubah bahan baku/setengah jadi menjadi barang jadi yang pada umumnya dapat dikonsumsi oleh perusahaan lain, rumah tangga atau pribadi akan digolongkan ke dalam sektor CGI.

Barang yang dihasilkan oleh perusahaan-perusahan di sektor CGI selalu dinantikan dan menjadi bagian dari kebutuhan masyarakat, maka sektor inilah yang menjadi paling dekat dengan masyarakat. Sehingga perusahaan dalam sektor ini selalu beroperasi, namun tidak menutup kemungkinan perusahaan di dalamnya mengalami kerugian. Pada tahun 2018 sektor CGI mengalami perlambatan pertumbuhan yang diakibatkan oleh beberapa faktor salah satunya yaitu persaingan antar perusahaan (Muamar, 2018).

Di sektor CGI perusahaan akan dikelompokkan berdasarkan jenis barang yang diproduksi (yang kemudian dikelompokkan sebagai subsektor). Pada tahun 2018 terdapat enam subsektor dari sektor CGI, dengan total jumlah 53 perusahaan di dalamnya. Diantaranya 27 perusahaan subsektor food and beverage, 5 perusahaan subsektor tobacco manufacturers, 10 perusahaan subsektor pharmaceuticals, 6 perusahaan subsektor cosmetics and huosehold, 4 perusahaan subsektor houseware, dan 1 perusahaan subsektor other.

Pada rentang tahun 2017 dan 2018 setiap subsektor mengalami pertumbuhan yang beragam. Pada akhir tahun 2018, yaitu tepatnya pada bulan Nopember 2018, indeks harga saham perusahaan sektor CGI mengalami anjlok 3,83\%, (Kevin, 2018). Saham-saham sektor CGI banyak yang dilepas investor, diantaranya HMSP (PT HM Sampoerna Tbk, UNVR (PT 


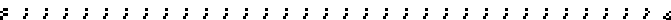

: Widya Akuntansi dan Keuangan

: Universitas Hindu Indonesia

Edisi Agustus 2020

Unilever Indonesia Tbk), GGRM (PT Gudang Garam Tbk), dan INDF (PT Indofood Sukses Makmur Tbk).

Lalu bagaimana dengan kinerja keuangan perusahaan sektor CGI secara umum pada tahun 2018? Penelitian ini berupaya untuk menggambarkan kinerja keuangan perusahaan tersebut melalui pendekatan analisis common size dan analisis rasio keuangan.

Beberapa penelitian sebelumnya telah menggunakan rasio keuangan untuk menggambarkan kinerja keuangan perusahaan sektor CGI (Barus et al., 2017; Martiani, 2019; Nazariah et al., 2019). Namun, penelitian sebelumnya berfokus pada satu subsektor yang ada di sektor CGI. Sedangkan penulis tertarik untuk melakukan penelitian mengenai kinerja sektor CGI secara umum pada tahun 2018.

\section{METODE}

Metode penelitian yang digunakan pada penelitian ini yaitu metode penelitian deskriptif. Penelitian deskriptif berupaya mendeskripsikan gejala, peristiwa ataupun kejadian yang sedang terjadi (Sujarweni, 2015). Dilihat dari jenis datanya penelitian ini menggunakan pendekatan kuantitatif, dimana data yang digunakan berupa angka, yang kemudian digunakan sebagai alat analisis untuk memperoleh pengetahuan atau mendeskripsikan peristiwa yang terjadi (Sujarweni, 2015).

Data yang digunakan merupakan data sekunder, berupa laporan keuangan perusahaan sektor CGI periode tahun 2017 - 2018 yang dipublikasikan di BEI melalui laman web www.idx.co.id. Data yang digunakan yaitu laporan keuangan 53 perusahaan. Sumber teori diperoleh melalui riset pustaka dan penelitian sejenis yang didapat dari jurnal penelitian.

Analisis rasio keuangan perusahaan dilakukan dengan rumus-rumus rasio keuangan berikut ini (Fahmi, 2015):

Tabel 1

\section{Rumus Rasio Keuangan}

\begin{tabular}{clc}
\hline No. & \multicolumn{1}{c}{ Jenis Rasio } & Rumus Rasio Keuangan \\
\hline 1. & Rasio Likuiditas \\
adalah rasio yang menggambarkan besar kemampuan perusahaan memenuhi kewajiban \\
(utang) jangka pendeknya, baik kepada pihak eksternal maupun internal.
\end{tabular}




\section{b. Quick Ratio}

Rasio ini digunakan untuk melihat kemampuan entitas/perusahaan melunasi kewajiban (utang) jangka pendek dengan aset lancar tanpa memperhitungkan nilai persediaan, karena persediaan $=\frac{\text { Aset Lancar }- \text { Persediaan }}{\text { Utang Lancar }}$ dianggap memerlukan waktu relatif lama untuk diuangkan.

\section{Rasio Solvabilitas}

digunakan untuk melihat kemampuan perusahaan membayar seluruh kewajiban perusahaan baik jangka panjang maupun jangka pendek.

a. Debt to Asset Ratio

Rasio ini digunakan untuk membandingkan antara total kewajiban dengan total aset yang menunjukkan seberapa besar total aset perusahaan dibiayai oleh kewajiban atau seberapa besar kewajiban $=\frac{\text { Total Utang }}{\text { Total Aset }}$ perusahaan berpengaruh terhadap aset.

b. Debt to Equity Ratio

Digunakan untuk menilai perbandingan kewajiban dengan ekuitas. Melalui rasio ini dapat dihitung seberapa besar ekuitas yang dapat $=\frac{\text { Total Utang }}{\text { Total Ekuitas }}$ dijadikan untuk jaminan kewajiban.

\section{Rasio Aktivitas}

digunakan untuk menilai efesiensi dan efektifitas perusahaan dalam memanfaatkan sumberdaya atau aset, sehingga hasilnya menunjukkan seberapa baik perusahaan dalam menggunakan aset yang dimilikinya.

\section{a. Total Asset Turnover}

Rasio ini mengukur seberapa efesien pengelolaan persediaan dalam perusahaan, dengan mengukur berapa kali persediaan dijual selama periode

$$
=\frac{\text { Penjualan }}{\text { Total Aset }}
$$
tertentu.

\section{b. Fixed Asset Turnover}

Rasio ini menunjukkan bagaimana perubahaan dalam menggunakan aset tetap yang dimilikinya seperti kendaraan, mesin, gedung dan lainnya.

$$
=\frac{\text { Penjualan }}{\text { Total Aset Tetap }}
$$

\section{Rasio Profitabilitas}

digunakan untuk mengetahui kemampuan sebuah perusahaan dalam memeroleh laba dari pendapatan yang terkait dengan penjualan, aset dan modal.

a. Gross Profit Margin

Digunakan untuk menilai laba kotor yang telah

diperoleh dari hasil penjualan.

$$
=\frac{\text { Laba Kotor }}{\text { Penjualan }}
$$

b. Return on Assets

Digunakan untuk menilai keuntungan (return) yang diterima perusahaan dalam mengelola asetnya sehingga sumberdaya yang dimiliki

$$
=\frac{\text { Laba Bersih }}{\text { Total Aset }}
$$




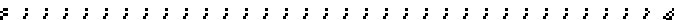

- Widya Akuntansi dan Keuangan

: Universitas Hindu Indonesia

Edisi Agustus 2020

c. Return on Equity

Digunakan untuk perusahan mengetahui kemampuannya dalam memperoleh laba

$$
=\frac{\text { Laba Bersih }}{\text { Ekuitas }}
$$

Sumber: Fahmi (2015)

Penjelasan deskriptif kemudian dilakukan untuk menggambarkan temuan dari hasil analisis data terkait. Penjelasan tersebut diantaranya keterkaitan dengan sumber teori yang diperoleh melalui riset pustaka dan penelitian sejenis yang didapat dari jurnal penelitian.

\section{HASIL DAN PEMBAHASAN}

\section{Gambaran Umum Subjek Penelitian}

Terdapat 53 perusahaan sebagai subjek penelitian Perusahaan tersebut digolongkan berdasarkan subsektor dan ukuran perusahaan. Ukuran perusahaan dikategorikan berdasarkan jumlah penjualan pada tahun 2018, dengan ketentuan sebagaimana Tabel 2 berikut ini:

\section{Tabel 2}

\section{Ketentuan Ukuran Perusahaan}

\begin{tabular}{ll}
\hline Ukuran & Kategori \\
\hline Small & Penjualan sampai dengan 500 Milyar Rupiah \\
Medium & Penjualan dari 500 Milyar hingga 1 Triliun Rupiah \\
Large & Penjualan dari 1 Triliun hingga 2 Triliun Rupiah \\
Super & Penjualan di atas 2 Triliun Rupiah \\
\hline
\end{tabular}

Maka bila dilihat berdasarkan ukuran dan subsektornya maka distribusi perusahaan dalam sektor CGI ditunjukkan pada Tabel 3 berikut ini:

Tabel 3

Distribusi Perusahaan Berdasarkan Subsektor dan Ukuran

\begin{tabular}{lccccr}
\hline \multirow{2}{*}{ Subsektor } & \multicolumn{4}{c}{ Ukuran Perusahaan } & Total \\
\cline { 2 - 5 } & Small & Medium & Large & Super & Persen \\
\hline Food and Beverage & 7 & 6 & 4 & 10 & 50,94 \\
Tobacco Manufacturers & 1 & 0 & 1 & 3 & 9,43 \\
Pharmaceuticals & 1 & 1 & 3 & 5 & 18,87 \\
Cosmetics and Household & 2 & 1 & 0 & 3 & 11,32 \\
Houseware & 3 & 0 & 0 & 1 & 7,55 \\
Other & 0 & 0 & 0 & 1 & 1,89 \\
\hline Jumlah perusahaan & 14 & 8 & 8 & 23 & 100,00 \\
\hline Persentase dari total & 26,42 & 15,09 & 15,09 & 43,40 & 100,00 \\
\hline Sumber: Data diolah (2020) & \multicolumn{5}{c}{}
\end{tabular}


Tabel 3 di atas menunjukkan dominasi perusahaan berukuran super di sektor CGI (dengan penjualan di atas 2 Triliun Rupiah per tahun), yaitu sebanyak 23 perusahaan atau mencapai 43,40\% dari total 53 perusahaan. Hal ini setidaknya menunjukkan pula kontribusi yang besar sektor ini bagi IHSG (Fajrian, 2019).

\section{Analisis Common Size}

Analisis common size dilakukan dengan cara menghitung jumlah dari tiap akun di laporan posisi keuangan (neraca) dan laporan laba rugi menjadi proporsi (persentase) dari jumlah total aset (untuk laporan posisi keuangan) atau total penjualan (untuk laporan laba rugi) (Hanafi \& Halim, 2012; Aminah \& Hidayat, 2016).

\section{Analisis Common Size Laporan Posisi Keuangan}

Aset dalam laporan posisi keuangan mewakili apa yang dimiliki oleh perusahaan. Kewajiban merupakan keharusan perusahaan untuk membayar utang kepada perusahaan atau pihak lain pada masa tertentu di masa depan. Ekuitas menyajikan investasi para pemilik saham dan modal pemilik perusahaan dalam sektor. Berikut ini disajikan analisis common size laporan posisi keuangan kumulatif perusahaan-perusahaan sektor CGI di BEI tahun 2018 dan 2017: 
Tabel 4

Common Size Laporan Posisi Keuangan Seluruh Perusahaan Sektor CGI Tahun 2018 dan 2017

\begin{tabular}{|c|c|c|c|}
\hline \multirow{2}{*}{ ITEM } & \multicolumn{2}{|c|}{ TAHUN } & \multirow{2}{*}{$\begin{array}{l}\text { Naik/ } \\
\text { Turun }\end{array}$} \\
\hline & 2018 & 2017 & \\
\hline \multicolumn{4}{|l|}{ ASSETS } \\
\hline \multicolumn{4}{|l|}{ Current Assets } \\
\hline Cash and cash equivalents & 12,20 & 13,50 & $(1,30)$ \\
\hline Trade receivables & 10,78 & 11,19 & $(0,40)$ \\
\hline Non-trade receivables & 0,84 & 1,04 & $(0,20)$ \\
\hline Inventory & 24,83 & 25,76 & $(0,92)$ \\
\hline Prepaid Expense & 0,43 & 0,43 & $(0,00)$ \\
\hline Other Current Assets & 4,69 & 3,74 & 0,95 \\
\hline Total current assets & 53,77 & 55,65 & $(1,88)$ \\
\hline \multicolumn{4}{|l|}{ Non-current assets } \\
\hline Investments & 2,22 & 2,06 & 0,16 \\
\hline Property, plant and equipment & 35,32 & 34,84 & 0,48 \\
\hline Other Non Current Assets & 8,70 & 7,45 & 1,25 \\
\hline Total non-current assets & 46,23 & 44,35 & 1,88 \\
\hline TOTAL ASSETS & 100,00 & 100,00 & - \\
\hline \multicolumn{4}{|l|}{ LIAB ILITIES AND EQUITY } \\
\hline \multicolumn{4}{|l|}{ LIAB ILITIES } \\
\hline \multicolumn{4}{|l|}{ Current liabilities } \\
\hline Short-term loans & 12,50 & 12,43 & 0,07 \\
\hline Trade payables & 6,68 & 7,25 & $(0,57)$ \\
\hline Other Current Payables & 5,99 & 4,37 & 1,62 \\
\hline Current accrued expenses & 2,69 & 2,53 & 0,15 \\
\hline Taxes payable & 1,34 & 1,20 & 0,14 \\
\hline Total current liabilities & 29,19 & 27,78 & 1,42 \\
\hline \multicolumn{4}{|l|}{ Non-current liabilities } \\
\hline Long-term liabilities & 10,45 & 12,04 & $(1,59)$ \\
\hline Total non-current liabilities & 10,45 & 12,04 & $(1,59)$ \\
\hline TOTAL LIAB ILITIES & 39,65 & 39,82 & $(0,17)$ \\
\hline \multicolumn{4}{|l|}{ EQUITY } \\
\hline Common Stock & 4,29 & 4,58 & $(0,29)$ \\
\hline Other Equity & 15,33 & 15,94 & $(0,61)$ \\
\hline Retained earnings (deficit) & 35,89 & 34,71 & 1,18 \\
\hline $\begin{array}{l}\text { Total equity attributable to e quity owners } \\
\text { of parent entity }\end{array}$ & 55,51 & 55,23 & 0,28 \\
\hline Non-controlling interests & 4,84 & 4,95 & $(0,11)$ \\
\hline TOTAL EQUITY & 60,35 & 60,18 & 0,17 \\
\hline TOTAL LIAB ILITIES AND EQUITY & 100,00 & $\mathbf{1 0 0 , 0 0}$ & - \\
\hline
\end{tabular}

Sumber: Data diolah (2020) 


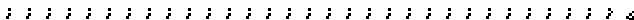

- Widya Akuntansi dan Keuangan

: Universitas Hindu Indonesia

Edisi Agustus 2020

Tabel 4 di atas menunjukkan di sisi aset, persentase aset tanah, bangunan, dan peralatan mendominasi proporsi total aset secara keseluruhan. Bila diperhatikan trend tahun 2017 ke 2018 mengalami kenaikan. Hal ini menunjukkan terjadinya peningkatan atau investasi padat modal yang cukup besar yang dilakukan perusahaan-perusahaan sektor CGI.

Kemudian pada tahun 2018 persentase kas dan setara kas terhadap total aset terlihat turun dari tahun sebelumnya. Penurunan ini bila diperhatikan mengakibatkan persentase kas dan setara kas terhadap total aset lebih rendah dibanding persentase utang lancar terhadap total liabilitas dan ekuitas. Kondisi tersebut menggambarkan bahwa kemampuan perusahaan membiayai kewajiban jangka pendeknya rendah.

Jumlah kas dan dan setara kas yang kecil akan mengganggu aktivitas perusahaan, karena perusahaan kekurangan dana yang likuid untuk membiayai pengeluaran rutin maupun pengeluaran yang tidak rutin. Sebaliknya jumlah kas yang terlalu besar pada perusahaan menunjukkan jumlah dana yang tidak digunakan (menganggur). Semakin banyak dana menganggur berarti semakin banyak nilai investasi yang hilang.

Persentase piutang usaha terhadap total aset cukup besar pada tahun 2018 dan 2017. Kondisi ini setidaknya menunjukkan kemampuan perusahaan mengelola piutang kurang baik. Semakin tinggi piutang menunjukkan semakin banyak modal kerja tertanam dalam piutang yang tidak dapat dimanfaatkan oleh perusahaan dan semakin tinggi pula risiko piutang tidak tertagih.

Persentase persediaan terhadap total aset pada tahun 2018 cukup tinggi, walaupun turun dari tahun sebelumnya. Tingginya tingkat persediaan tidak menguntungkan perusahaan karena dapat menimbulkan biaya penyimpanan, risiko kerusakan dan menghambat cash flow karena banyaknya dana yang tertanam pada persediaan (dana menganggur).

Lalu di sisi kewajiban, kewajiban jangka pendek memiliki proporsi tertinggi dibanding komponen kewajiban lainnya. Tingginya persentase kewajiban jangka pendek bisa mengindikasikan terjadi peningkatan aktivitas perusahaan sehingga memerlukan utang kepada pihak ketiga untuk memenuhi kebutuhan operasional. Semakin tinggi persentase kewajiban jangka pendek dapat meningkatkan risiko yang dihadapi. Namun jika kenaikan kewajiban jangka pendek dapat memenuhi pembiayaan aktivitas perusahaan sehingga perusahaan secara optimal dapat meningkatkan produktivitasya dan perusahaan lebih dapat 
mengembangkan bisnisnya, serta dengan peningkatan tersebut juga mampu meningkatkan laba, maka keputusan untuk menambah kewajiban lancar sudah tepat.

Persentase ekuitas terhadap total liabilitas dan ekuitas pada tahun 2018 meningkat dari tahun sebelumnya. Kondisi ini menunjukkan aset yang didanai oleh modal yang dimiliki perusahaan meningkat dibanding yang didanai dari utang.

\section{Analisis Common Size Laporan Laba Rugi}

Untuk melihat hasil usaha operasional perusahaan selama setahun terakhir dan termasuk tahun sebelumnya dapat dilihat melalui laporan laba rugi. Dalam laporan tersebut tersajikan daftar pendapatan dan beban perusahaan dalam jangka waktu tertentu. Sehingga dapat dilihat profitabilitas perusahaan pada waktu tersebut, meskipun tidak menunjukkan arus kas perusahaan. Berikut ini disajikan analisis common size laporan posisi keuangan kumulatif perusahaan-perusahaan sektor CGI di BEI tahun 2018 dan 2017:

\section{Tabel 5}

\section{Common Size Laporan Laba Rugi Seluruh Perusahaan Sektor CGI Tahun 2018 dan 2017}

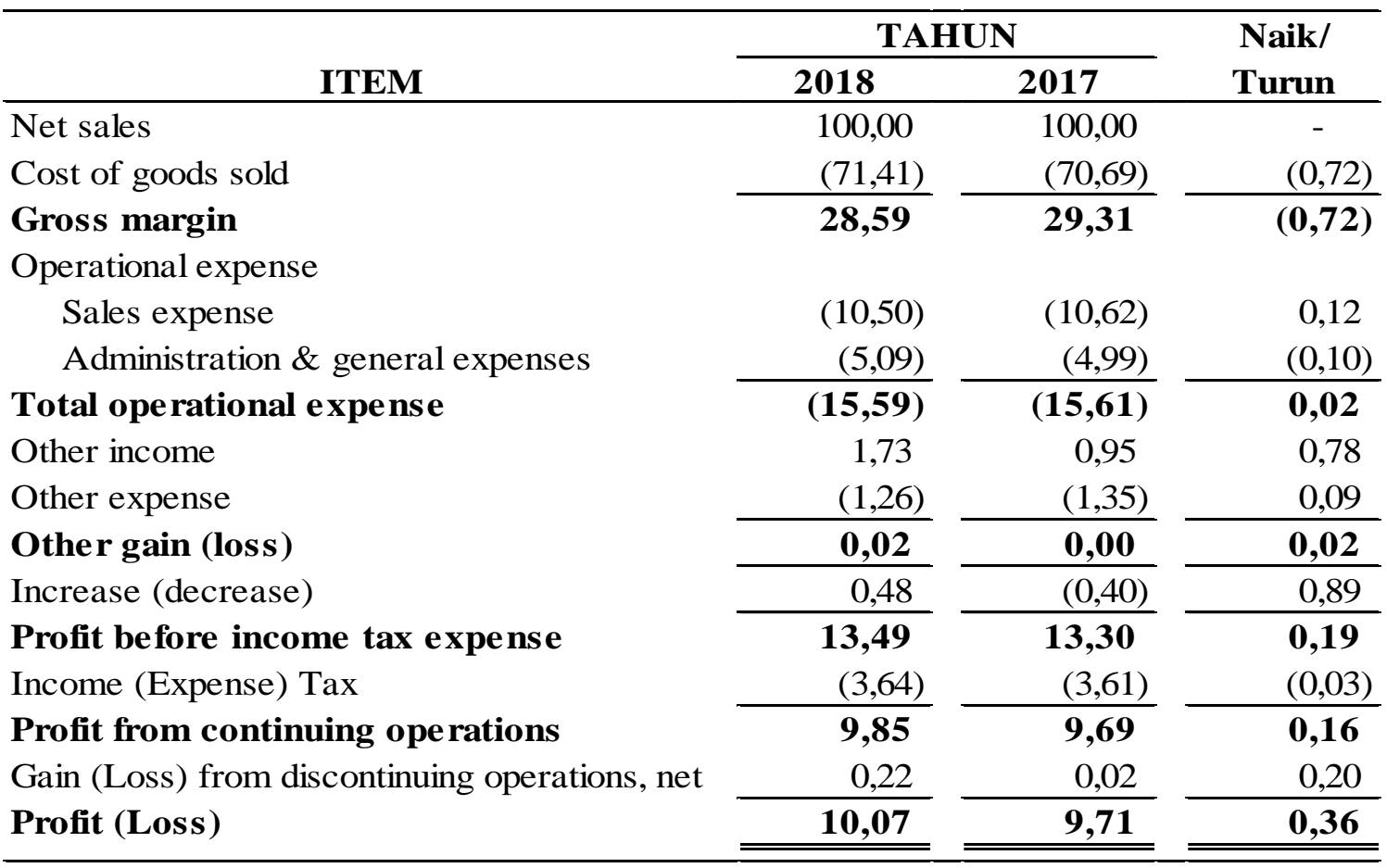

Sumber: Data diolah (2020)

Tabel 5 di atas menunjukkan persentase harga pokok penjualan terhadap penjualan bersih pada tahun 2018 meningkat dibanding tahun sebelumnya. Hal ini menyebabkan turunnya laba kotor. Namun bila dilihat dari persentase beban operasi terhadap penjualan 


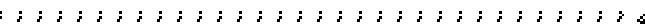

- Widya Akuntansi dan Keuangan

: Universitas Hindu Indonesia

Edisi Agustus 2020

bersih terjadi penurunan, sehingga laba operasi meningkat. Bahkan sampai dengan laba bersih setelah pajak pun akhirnya terjadi peningkatan sebesar $0,36 \%$ dari tahun sebelumnya. Kondisi tersebut menunjukkan kemampuan perusahaan untuk menghasilkan laba bersih setelah pajak berdasarkan tingkat penjualannya semakin baik.

\section{Analisis Rasio Keuangan}

Analisis laporan keuangan akan mampu membantu menginterpretasikan berbagai keterkaitan dan kecenderungan yang dapat memberikan dasar pengambilan keputusan dalam mempertimbangkan potensi keberhasilan perusahaan untuk masa akan datang. Cara yang dipakai dalam menilai kinerja perusahaan salah satunya dengan melakukan analisis rasio keuangan.

Rasio dapat mengukur tingkat kinerja perusahaan yang berdampak kepada keuangan dan operasional. Dengan kinerja perusahaan yang baik akan membantu manajemen perusahaan mencapai tujuan perusahaan. Rasio keuangan yang biasanya digunakan dalam analisis adalah rasio likuiditas, rasio solvabilitas, rasio aktivitas, dan rasio profitabilitas.

\section{Rasio Likuiditas}

Berikut ini disajikan rasio likuiditas kumulatif perusahaan-perusahaan sektor CGI di BEI tahun 2018 dan 2017:

Tabel 6

Rasio Likuiditas Seluruh Perusahaan Sektor CGI Tahun 2018 dan 2017

\begin{tabular}{lcccccc}
\hline \multirow{2}{*}{\multicolumn{1}{c}{ Subsektor }} & \multicolumn{2}{c}{ Curre nt Ratio } & & \multicolumn{2}{c}{ Quick Ratio } \\
\cline { 2 - 3 } \cline { 6 - 7 } & $\mathbf{2 0 1 8}$ & $\mathbf{2 0 1 7}$ & & $\mathbf{2 0 1 8}$ & $\mathbf{2 0 1 7}$ \\
\hline Food And Beverage & 1,47 & 1,81 & & 1,01 & 1,35 \\
Tobacco Manufacturers & 2,52 & 2,58 & & 0,90 & 0,75 \\
Pharmaceuticals & 2,36 & 2,66 & & 1,64 & 1,83 \\
Cosmetics And Household & 0,95 & 0,84 & & 0,65 & 0,60 \\
Houseware & 1,37 & 1,32 & & 0,55 & 0,51 \\
Other & 3,69 & 3,78 & & 2,11 & 2,17 \\
\hline Sektor Industri Barang Kons umsi & $\mathbf{1 , 8 4}$ & $\mathbf{2 , 0 0}$ & & $\mathbf{1 , 0 0}$ & $\mathbf{1 , 1 0}$ \\
\hline
\end{tabular}

Sumber: Data diolah (2020)

Tabel 6 di atas menunjukkan hasil perhitungan rasio likuiditas, yang terdiri dari current ratio dan quick ratio. Apabila dilihat dari hasil perhitungan current ratio, sektor CGI memiliki kemampuan dalam hal melunasi kewajiban jangka pendeknya menggunakan aset lancar lebih baik pada tahun 2017 dibanding tahun 2018. Hal ini diakibatkan peningkatan 


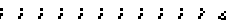

: Widya Akuntansi dan Keuangan

: Universitas Hindu Indonesia

Edisi Agustus 2020

kewajiban jangka pendek yang lebih besar dibanding peningkatan aset lancar (Tabel 4). Apabila dibandingkan berdasarkan subsektor, maka subsektor other memiliki kemampuan lebih baik dibanding subsektor lainnya. Secara umum, rata-rata setiap subsektor mengalami penurunan current ratio dari tahun 2017 ke tahun 2018.

Selanjutnya apabila dilihat dari perbandingan quick ratio, dimana merupakan pengukuran untuk menunjukkan besar kemampuan perusahaan melunasi kewajiban jangka pendeknya menggunakan aset lancar tanpa persediaan, subsektor other memiliki kemampuan lebih baik dibanding subsektor lainnya pada tahun 2017 dan mengalami penurunan pada tahun 2018, disusul oleh subsektor Pharmaceuticals dan subsektor Food and Beverage.

\section{Rasio Solvabilitas}

Berikut ini disajikan rasio solvabilitas kumulatif perusahaan-perusahaan sektor CGI di BEI tahun 2018 dan 2017:

Tabel 7

Rasio Solvabilitas Seluruh Perusahaan Sektor CGI Tahun 2018 dan 2017

\begin{tabular}{lcccccc}
\hline \multirow{2}{*}{\multicolumn{1}{c}{ Subsektor }} & \multicolumn{2}{c}{ Debt to Assets } & & \multicolumn{2}{c}{ Debt to Equity } \\
\cline { 2 - 3 } \cline { 6 - 7 } & $\mathbf{2 0 1 8}$ & $\mathbf{2 0 1 7}$ & & $\mathbf{2 0 1 8}$ & $\mathbf{2 0 1 7}$ \\
\hline Food And Beverage & 0,44 & 0,45 & & 0,79 & 0,81 \\
Tobacco Manufacturers & 0,32 & 0,31 & & 0,47 & 0,45 \\
Pharmaceuticals & 0,35 & 0,30 & & 0,53 & 0,44 \\
Cosmetics And Household & 0,53 & 0,62 & & 1,15 & 1,61 \\
Houseware & 0,46 & 0,48 & & 0,84 & 0,92 \\
Other & 0,29 & 0,30 & & 0,41 & 0,42 \\
\hline Sektor Indus tri Barang Konsumsi & $\mathbf{0 , 4 0}$ & $\mathbf{0 , 4 0}$ & & $\mathbf{0 , 6 6}$ & $\mathbf{0 , 6 6}$ \\
\hline
\end{tabular}

Sumber: Data diolah (2020)

Berdasarkan tabel 7 di atas, dapat dilihat bahwa dari tahun 2017 ke tahun 2018 sektor CGI bergerak stabil baik pada debt to asset ratio maupun debt to equity ratio. Pada debt to asset ratio, apabila dilihat berdasarkan subsektor pada tahun 2017 dan 2018, angka rasio tertinggi dimiliki oleh subsektor Cosmetics and Household. Debt to asset ratio yang tinggi dalam beberapa kasus dapat menurunkan nilai perusahaan (Zulkarnain \& Farida, 2018).

Sebaliknya rasio terendah debt to equity ratio dimiliki oleh subsektor other. Begitu pula untuk nilai debt to equity ratio. Nilai rasio yang rendah menguntungkan bagi sektor other karena pihak kreditor akan menyediakan dana besar jika akan melakukan pinjaman, dengan pertimbangan tingkat keamanan dan risiko relatif kecil. 


\section{Rasio Aktivitas}

Berikut ini disajikan rasio aktivitas kumulatif perusahaan-perusahaan sektor CGI di BEI tahun 2018 dan 2017:

\section{Tabel 8}

Rasio Aktivitas Seluruh Perusahaan Sektor CGI Tahun 2018 dan 2017

\begin{tabular}{lccccc}
\hline \multirow{2}{*}{ Subsektor } & \multicolumn{2}{c}{ T-Asset Turnover } & & F-Asset Turnover \\
\cline { 2 - 3 } \cline { 6 - 7 } & $\mathbf{2 0 1 8}$ & $\mathbf{2 0 1 7}$ & & $\mathbf{2 0 1 8}$ & $\mathbf{2 0 1 7}$ \\
\hline Food And Beverage & 0,94 & 0,96 & & 2,35 & 2,43 \\
Tobacco Manufacturers & 1,71 & 1,63 & & 6,29 & 6,06 \\
Pharmaceuticals & 1,04 & 1,14 & & 3,29 & 3,81 \\
Cosmetics And Household & 1,82 & 1,86 & & 3,65 & 3,71 \\
Houseware & 0,50 & 0,50 & & 1,21 & 1,19 \\
Other & 1,79 & 1,75 & & 29,86 & 26,07 \\
\hline Sektor Indus tri Barang Kons umsi & $\mathbf{1 , 2 6}$ & $\mathbf{1 , 2 6}$ & & $\mathbf{3 , 5 7}$ & $\mathbf{3 , 6 3}$ \\
\hline
\end{tabular}

Sumber: Data diolah (2020)

Total asset turnover sektor CGI secara keseluruhan bergerak stabil dari tahun 2017 ke tahun 2018. Subsektor Houseware juga menunjukkan nilai total asset turnover yang sama pada kedua tahun tersebut. Rasio tertinggi pada tahun $2018(1,82)$ terjadi di subsektor Cosmetics and Household, walaupun menunjukkan penurunan efektifitasnya dalam penggunaan total aset dari tahun sebelumnya $(1,86)$.

Fixed asset turnover sektor CGI secara keseluruhan mengalami penurunan sebesar 0,06 persen dari $(3,63)$ tahun 2017 ke $(3,57)$ tahun 2018. Berbanding terbalik dengan penurunan sektor CGI secara keseluruhan, subsektor Other pada tahun 2018 mengalami peningkatan sebesar 3,79 persen dari tahun sebelumnya yang menunjukkan adanya pertumbuhan efektifitas dalam penggunaan aset tetap.

\section{Rasio Profitabilitas}

Berikut ini disajikan rasio aktivitas kumulatif perusahaan-perusahaan sektor CGI di BEI tahun 2018 dan 2017: 
ijizizo

: Widya Akuntansi dan Keuangan

: Universitas Hindu Indonesia

Edisi Agustus 2020

Tabel 9

Rasio Profitabilitas Seluruh Perusahaan Sektor CGI Tahun 2018 dan 2017

\begin{tabular}{|c|c|c|c|c|c|c|}
\hline \multirow{2}{*}{ Subsektor } & \multicolumn{2}{|c|}{ GPM } & \multicolumn{2}{|c|}{ ROA } & \multicolumn{2}{|c|}{ ROE } \\
\hline & 2018 & 2017 & 2018 & 2017 & 2018 & 2017 \\
\hline Food And Beverage & 0,29 & 0,29 & 0,08 & 0,08 & 0,14 & 0,14 \\
\hline Tobacco Manufacturers & 0,21 & 0,22 & 0,16 & 0,16 & 0,23 & 0,23 \\
\hline Pharmaceuticals & 0,42 & 0,42 & 0,12 & 0,11 & 0,19 & 0,16 \\
\hline Cosmetics And Household & 0,49 & 0,50 & 0,35 & 0,28 & 0,74 & 0,73 \\
\hline Houseware & 0,31 & 0,30 & 0,03 & 0,03 & 0,06 & 0,06 \\
\hline Other & 0,09 & 0,09 & 0,08 & 0,08 & 0,11 & 0,11 \\
\hline $\begin{array}{l}\text { Sektor Industri Barang } \\
\text { Konsumsi }\end{array}$ & $\mathbf{0 , 2 9}$ & $\mathbf{0 , 2 9}$ & $\mathbf{0 , 1 3}$ & $\mathbf{0 , 1 2}$ & $\mathbf{0 , 2 1}$ & $\mathbf{0 , 2 0}$ \\
\hline
\end{tabular}

Sumber: Data diolah (2020)

Gross profit margin sektor CGI secara keseluruhan pada tahun 2018 dan 2017 adalah sama pada nilai 0,29. Penjualan meningkat pada tahun 2018, namun diikuti pula dengan kenaikan harga pokok penjualan. Penjualan meningkat sebesar 8,08 persen dan harga pokok penjualan meningkat sebesar 9,18 persen. Berdasarkan subsektor, gross profit margin tertinggi $(0,49)$ terjadi pada subsektor Cosmetics and Household yang memperoleh laba kotor sebesar 49,27 persen dari total penjualan bersih 48 Triliun Rupiah pada tahun 2018. Sedangkan rasio terendah $(0,09)$ terjadi pada subsektor other yang memperoleh laba kotor sebesar 9,40 persen dari total penjualan bersih 2,7 Triliun Rupiah.

Return on assets sektor CGI secara keseluruhan pada tahun 2018 dan 2017 meningkat tidak signifikan sebesar 0,01 persen. Pada tahun 2017 ROA secara keseluruhan sebesar 0,12, kemudian pada tahun selanjutnya sebesar 0,13 . Bila dilihat berdasarkan subsektor, rasio tertinggi pada tahun 2018 terjadi pada subsektor Cosmetics and Household, sedangkan subsektor lainnya rasionya masih di bawah nilai 0,20 . Hal ini dikarenakan subsektor Cosmetics and Household mendapatkan laba bersih 19,04 persen dari total penjualan pada tahun tersebut. Investor sangat memperhatikan ROA perusahaan (Zulkarnain et al., 2020). Investor memiliki orientasi menginginkan return yang tinggi dari investasi.

Return on equity sektor CGI secara keseluruhan pada tahun 2018 dan 2017 pun meningkat tidak signifikan sebesar 0,01 persen. Pada tahun 2017 ROE secara keseluruhan sebesar 0,20, kemudian pada tahun selanjutnya sebesar 0,21. Bila dilihat berdasarkan subsektor, rasio tertinggi $(0,74)$ pada tahun 2018 terjadi pada subsektor Cosmetics and Household, yang mengalami peningkatan ROE dibanding tahun sebelumnya. Hal ini 


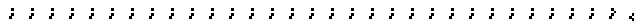

: Widya Akuntansi dan Keuangan

: Universitas Hindu Indonesia

Edisi Agustus 2020

menunjukkan subsektor Cosmetics and Household memilki kemampuan yang lebih baik untuk memberikan laba kepada pemegang saham dibandingkan subsektor lainnya.

\section{SIMPULAN}

Penelitian ini memberikan gambaran kinerja perusahaan di sektor CGI-BEI pada tahun 2018 dan 2017. Sektor CGI dalam penjualan bersih mengalami peningkatan sebesar 8,08\%. Hal ini berkontribusi positif terhadap terjadinya peningkatan laba bersih sebesar $0,36 \%$ dari penjualan bersih. Rata-rata laba bersih perusahaan di sektor CGI pada tahun 2018 mencapai 1 Triliun Rupiah. Meski terjadi penurunan 2,02\% pada kas dan setara kas, peningkatan yang cukup tinggi terjadi pada persediaan, investasi, dan aset tetap. Di sisi lain, kewajiban juga meningkat sebesar 7,93\% dan ekuitas meningkat sebesar 8,40\%.

Pertumbuhan atau penurunan kinerja keuangan yang terjadi pada sektor CGI juga tergambarkan pada hasil analisis rasio keuangan berikut ini: (1) Rasio likuiditas, yang terdiri dari current ratio dan quick ratio. Keduanya mengalami penurunan, dimana current ratio pada periode sebelumnya tahun 2017 sebesar 2,00 menurun menjadi 1,84 pada periode selanjutnya tahun 2018. Begitu pula quick ratio pada tahun 2017 sebesar 1,10, kemudian turun menjadi 1,00 pada tahun 2018; (2) Rasio solvabilitas, yang terdiri dari debt to asset ratio dan debt to equity ratio. Dari tahun 2017 ke 2018 kedua rasio tersebut bergerak stabil, dimana debt to asset ratio ditemukan sebesar 0,40. Sedangkan debt to equity ratio sebesar 0,66; (3) Rasio aktivitas, yang terdiri dari total asset turnover dan fixed asset turnover. Total asset turnover, dari hasil analisis menunjukkan tidak terdapat perubahan diantara tahun 2017 dan tahun 2018, keduanya berada di posisi 1,26. Sedangkan pada fixed asset turnover, terdapat sedikit penurunan dari sebesar 3,63 pada tahun 2017, turun menjadi 3,57 pada tahun 2018; (4) Rasio profitabilitas, yang terdiri dari gross profit margin, return on assets, dan return on equity. Gross profit margin pada tahun 2017 dan 2018 bergerak stabil sebesar $0,29 \%$. Return on assets (ROA) mengalami sedikit peningkatan, yaitu sebesar $0,12 \%$ pada tahun 2017 dan meningat menjadi sebesar 0,13\% pada tahun 2018. Return on equity (ROE) pun mengalami peningkatan, yaitu sebesar $0,20 \%$ pada tahun 2017 dan meningkat menjadi 0,21\% pada tahun 2018 .

Penelitian ini memiliki keterbatasan pada jumlah rasio yang digunakan dalam analisis. Penelitian ini baru menggunakan sebagian kecil jenis rasio keuangan. Dengan keterbatasan 
ini, pada penelitian selanjutnya dapat mempertimbangkan menambah jenis rasio keuangan yang lain untuk memberikan gambaran utuh pengukuran kinerja perusahaan.

\section{DAFTAR RUJUKAN}

Aminah, S., \& Hidayat, I. (2016). Analisis Common Size Statement dan Trend untuk Menilai Kinerja Keuangan PT KAI. Jurnal Ilmu Dan Riset Manajemen (JIRM), 5(3), 1-25.

Barus, M. A., Sudjana, N., \& Sulasmiyati, S. (2017). Penggunaan Rasio Keuangan untuk Mengukur Kinerja Keuangan Perusahaan (Studi pada PT Astra Otoparts, Tbk dan PT Goodyear Indonesia, Tbk yang Go Public di Bursa Efek Indonesia). Jurnal Administrasi Bisnis, 44(1), 154-163.

Fahmi, I. (2015). Analisis Laporan Keuangan. Alfabeta.

Fajrian, H. (2019). Sektor Barang Konsumi Melesat Nyaris 2\%, IHSG Tembus 6.328,71. Katadata.Co.Id. https://katadata.co.id/happyfajrian/finansial/5e9a5576c5234/sektorbarang-konsumi-melesat-nyaris-2-ihsg-tembus-632871

Gumanti, T. A. (2011). Manajemen Investasi: Konsep, Teori, dan Aplikasi. Mitra Wacana Media.

Hanafi, M. M., \& Halim, A. (2012). Analisis Laporan Keuangan, Edisi Keempat. UPP STIM YKPN.

Kevin, A. (2018). Sektor Barang Konsumsi Anjlok 3,83\%, Time to Buy? Cnbcindonesia.Com. https://www.cnbcindonesia.com/market/20181109150142-1741413/sektor-barang-konsumsi-anjlok-383-time-to-buy

Martiani, N. L. D. (2019). Pengaruh Rasio Keuangan Terhadap Harga Saham pada Perusahaan Manufaktur Sektor Industri Barang Konsumsi yang Terdaftar di Bursa Efek Indonesia Periode Tahun 2013-2016. Jurnal Pendidikan Ekonomi Undiksha, 10(2), 668-678.

Muamar, Y. (2018). Pertumbuhan Industri Barang Konsumsi Dinilai Melambat. Cnbcindonesia.Com. https://www.cnbcindonesia.com/market/20181019191302-1738252/pertumbuhan-industri-barang-konsumsi-dinilai-melambat

Munawir, S. (2014). Analisa Laporan Keuangan. Liberty.

Nazariah, Maisur, \& Masytari, A. (2019). Pengaruh Rasio Keuangan Terhadap Nilai Perusahaan (Perusahaan Manufaktur Sektor Industri Barang Konsumsi yang Terdaftar di BEI tahun 2013-2017). Jurnal Real Riset, 1(2), 61-69.

Sujarweni, V. W. (2015). Metodologi Penelitian Bisnis \& Ekonomi. Pustaka Baru Press.

Zulkarnain, Z., \& Farida, R. (2018). Peran Profitability dan Capital Structure dalam Memengaruhi Firm Value. Cakrawala, 1(2), 89-99.

Zulkarnain, Z., Syahara, R., \& Novitasari, Y. (2020). Pengaruh ROA dan DER Terhadap Stock Price pada Perusahaan Makanan dan Minuman yang Terdaftar di BEI Periode 2013-2017. Cakrawala, 3(1), 22-32. 